\title{
BIOLOGICAL OBSERVATIONS ON Tupiperla (PLECOPTERA: GRIPOPTERYGIDAE)
}

\author{
FROEHLICH, C. G. \\ Departamento de Biologia, FFCLRP, USP, CEP 14040-901, Ribeirão Preto, SP, Brazil \\ Correspondence to: Claudio G. Froehlich, Departamento de Biologia, FFCLRP, USP, CEP 14040-901, Ribeirão \\ Preto, SP, Brazil \\ Received December 10, 1998 - Accepted October 25, 1999 - Distributed August 31, 2000
}

\begin{abstract}
Tupiperla illiesi fly along the year in the coastal mountains of southeastern Brazil, with larger numbers during the warmer rainy season. In the seasonal tropical climate of Central Brazil and Serra do Cipó, MG, T. oliveirai and T. gracilis, respectively, fly along the year but the pattern is still not known. In the higher elevation (ca. $1600 \mathrm{~m}$ a.s.1.) of Campos do Jordão, SP, species of Tupiperla may not fly during the colder months. Seasonal size variation, a phenomenon still little understood, occurred both in tropical and subtropical climates of the states of Goiás and São Paulo.
\end{abstract}

Key words: Tupiperla, flight periods, seasonal size variation, Plecoptera, Brazil.

\section{RESUMO}

Na serra costeira do sudeste do Brasil encontram-se adultos de Tupiperla illiesi o ano todo, porém em maior número na estação quente-chuvosa. No clima tropical sazonal do Brasil Central e da Serra do Cipó, MG, T. oliveirai e T. gracilis, respectivamente, voam o ano todo, mas o padrão ainda não é conhecido. Em Campos do Jordão, SP, com altitudes maiores (ca. 1600 m a.n.m.), provavelmente não voam nos meses mais frios. A variação sazonal de tamanho, um fenômeno ainda pouco compreendido, ocorreu tanto em climas tropicais como em subtropicais dos Estados de Goiás e São Paulo.

Palavras-chave: Tupiperla, períodos de vôo, variação sazonal de tamanho, Plecoptera, Brasil.

\section{FLIGHT PERIODS}

The knowledge on the flight periods of tropical and subtropical aquatic insects is still limited, as compared with the northern temperate zone. This is, in particular, true for the Neotropical Region. The more extensive studies on seasonality in the tropics were made by $\mathrm{H}$. Wolda in Panama, and two articles referring to aquatic insects, one on Ephemeroptera (Wolda \& Flowers, 1985), the other on Trichoptera (McElravy et al., 1982), were published. Some conclusions are that species have extended flight periods and may occur throughout the year but may show seasonal peaks of abundance even in "non-seasonal" environments.
A study concerning the genera Kempnyia and Macrogynoplax in southeastern Brazil is presented by Froehlich (1991). Species of Kempnyia are mostly seasonal, flying during the rainy season. Some have extended emergence periods and others more restricted ones. Macrogynoplax flies the year round.

As regards Tupiperla, few areas have been collected regularly for adults. These are the biological stations of Boracéia (EBB) and Paranapiacaba (EBP) in São Paulo State, Serra do Cipó and nearby areas in Minas Gerais and Pirenópolis in Goiás. Collection data for species from these localities and data of two species from de State Park of Campos de Jordão (PECJ), São Paulo are presented in Table 1. 
TABLE 1

Number of adults of Tupiperla spp. collected by month. In each item the first number refers to males, the second to females and the third to their sum. Zeros indicate that no adults were collected in the month; dashes indicate no collections were made in the month. MG stands for Minas Gerais; EBB to the Boracéia Biological Station, GO to Goiás and PECJ for the Campos do Jordão State Park..

\begin{tabular}{|c|c|c|c|c|c|c|c|}
\hline & \multicolumn{2}{|c|}{ T. gracilis } & T. illiesi & EBB: not & T. oliveirai & T. modesta & T. robusta \\
\hline Month & MG & EBB & & collected & GO & PECJ & PECJ \\
\hline JAN & $1 / 0 / 1$ & $2 / 1 / 3$ & $15 / 10 / 25$ & $14 / 13 / 37$ & $1 / 0 / 1$ & $0 / 0 / 0$ & $0 / 0 / 0$ \\
\hline FEB & $4 / 5 / 9$ & $1 / 0 / 1$ & $12 / 7 / 19$ & $2 / 2 / 4$ & $1 / 1 / 2$ & $0 / 0 / 0$ & $1 / 0 / 1$ \\
\hline MAR & $1 / 1 / 2$ & $1 / 1 / 2$ & $7 / 7 / 14$ & $5 / 8 / 13$ & $1 / 2 / 3$ & $0 / 0 / 0$ & $21 / 4 / 25$ \\
\hline APR & $0 / 3 / 3$ & $0 / 3 / 3$ & $3 / 4 / 7$ & $0 / 0 / 0$ & $2 / 4 / 6$ & $0 / 0 / 0$ & $1 / 2 / 3$ \\
\hline MAY & $0 / 0 / 0$ & $0 / 0 / 0$ & $1 / 1 / 2$ & $0 / 0 / 0$ & $10 / 9 / 19$ & $0 / 0 / 0$ & $0 / 0 / 0$ \\
\hline JUN & $1 / 1 / 2$ & $0 / 0 / 0$ & $1 / 1 / 2$ & $0 / 0 / 0$ & $0 / 0 / 0$ & $-/ / /-$ & $-/ /-$ \\
\hline JUL & $0 / 1 / 1$ & $0 / 0 / 0$ & $1 / 0 / 1$ & $0 / 0 / 0$ & $0 / 0 / 0$ & $-/ /-$ & $-/-/-$ \\
\hline AUG & $0 / 0 / 0$ & $1 / 0 / 1$ & $4 / 2 / 6$ & $3 / 3 / 6$ & $0 / 0 / 0$ & $-/ /-$ & $-/-/-$ \\
\hline SEP & $1 / 0 / 1$ & $1 / 0 / 1$ & $3 / 5 / 8$ & $0 / 5 / 5$ & $2 / 1 / 3$ & $-/ / /-$ & $-/ /-$ \\
\hline OCT & $4 / 2 / 6$ & $1 / 0 / 1$ & $3 / 4 / 7$ & $5 / 5 / 10$ & $2 / 0 / 2$ & $3 / 3 / 6$ & $0 / 0 / 0$ \\
\hline NOV & $0 / 0 / 0$ & $1 / 1 / 2$ & $3 / 4 / 7$ & $3 / 9 / 12$ & $9 / 4 / 13$ & $9 / 6 / 15$ & $0 / 0 / 0$ \\
\hline DEC & $2 / 1 / 3$ & $1 / 0 / 1$ & $10 / 7 / 17$ & $10 / 4 / 14$ & $0 / 0 / 0$ & $1 / 1 / 2$ & $0 / 0 / 0$ \\
\hline TOTAL & $\mathbf{1 4 / 1 4 / 2 8}$ & $\mathbf{9 / 6 / 1 5}$ & $\mathbf{6 3 / 5 2 / 1 1 5}$ & $\mathbf{4 2 / 4 9 / 9 1}$ & $\mathbf{2 8 / 2 1 / 4 9}$ & $\mathbf{1 3 / 1 0 / 2 3}$ & $\mathbf{2 3 / 6 / 2 9}$ \\
\hline
\end{tabular}

EBP was visited regularly by myself from April 1963 to June 1964 in a total of 18 trips, but a light trap was used in only part of the period and no beating sheet collections were made, so few adults were collected; but a number emerged in the laboratory from mature nymphs. Collections in the EBB, made by the staff of the Museum of Zoology and by myself, covered all months of the year during many years, but with smaller effort during the colder months (May-July). In Table 1, the column "EBB, not collected" refers to specimens which had their sex registered but were released (at the time it was believed that all were T. gracilis), or were collected and given away. My students L. G. Oliveira (Pirenópolis, GO, T. oliveirai) and $\mathrm{H}$. Paprocki (Serra do Cipó, MG, $T$. gracilis) made one year long collections during their graduate studies. The material from Minas Gerais includes a few specimens collected by myself.

T. gracilis is common neither in Minas Gerais nor in the EBB, but the dispersion of the adults collected during the year indicates it flies the year round in both localities (Table 1); the low numbers during the year do not allow conclusions about a preferred emergence season.
T. illiesi is the commonest species in both biological stations In the EBB $87 \%$ of all Tupiperla collected belonged to this species, and so should do most of the specimens listed in the column not collected. Even taking into account the smaller effort during the colder months, it can be seen that adults are found in greater numbers during the rainier, warmer season that extends from October to March, but are also found in the colder, drier months.

T. oliveirai, from Central Brazil, apparently also fly the year round, despite its absence in some months. The largest number was collected in May, the second largest in November, but the significance of these peaks cannot be judged without more extended collections.

Of the species occurring in PECJ, T. gracilis and $T$. reichardti were collected from October to March, showing an extended flight period, but they were not collected in April and May, suggesting they do not fly during the colder months. As may be seen in Table 1, the other two species, T. modesta and $T$. robusta showed limited and disjunct emergence periods, the first having been collected from October to December, while the second in March and April. 
Sequential emergence is well known in temperate climates, and is regarded as one mechanism contributing to reproductive isolation (Zwick, 1980; Hynes, 1976). It should be noted that in our case those two species are respectively the smallest and the largest in the area, and that any ecological explanation should take this into account.

The conclusion is that the more abundant species in the coastal mountains of southeastern Brazil fly throughout the year, but in larger numbers during the warmer, rainier season. More tropical species, from the states of Minas Gerais and Goiás, fly also the year round, but it is still not possible to say if there are seasonal peaks. In the higher altitude of Campos do Jordão, Tupiperla (as well as other stoneflies) may not fly during the winter months.

\section{SEASONAL SIZE VARIATION}

In temperate climates it is a well-known phenomenon that adults of stoneflies that emerge early are larger than those which do so later in the season (Hynes, 1976). The causes of this phenomenon are still obscure, and one suggestion is that as the emergence season advances, the urge to emerge stimulates smaller nymphs to moult (Khoo, in Hynes, 1.c.). Froehlich (1990) detected seasonal size variation in Kempnyia in a tropical climate (Serra do Cipó, Minas Gerais State, $19^{\circ} 20^{\prime}$ S, $43^{\circ} 35$ W), but as species of Kempnyia show seasonal emergence, they would fit into the temperate pattern. Studies in the genus Tupiperla show that seasonal variation occur also in species that fly throughout the year, both in subtropical as in tropical climates.
Three species for which larger samples were available were analyzed. They are: T. illiesi from EBB ( $\left.23^{\circ} 30^{\prime} \mathrm{S}, 45^{\circ} 53^{\prime} \mathrm{W}\right)$ and EBP ( $\left.23^{\circ} 46^{\prime} \mathrm{S}, 46^{\circ} 19^{\prime} \mathrm{W}\right)$, both subtropical, T. eleonorae from Intervales State Park (around $24^{\circ} 20^{\prime} \mathrm{S}, 48^{\circ} 25^{\prime} \mathrm{W}$ ), also subtropical, and T. oliveirai from Pirenópolis, Goiás State $\left(15^{\circ} 48^{\prime} \mathrm{S}, 48^{\circ} 51^{\prime} \mathrm{W}\right)$, tropical seasonal. T. illiesi and T. oliveirai fly the year round, for T. eleonorae there are insufficient data. For the analyses, the forewing length was used as a measure of size.

Few adults of T. illiesi were available in June and July, the two coldest months, and these two months were not considered in the analysis. For an ANOVA procedure, adults were divided into three periods: I - August-November, corresponding to early emergence, II - December-February, to peak emergence, and III - March-May, to late emergence. The results are presented in Table 2. There is a significant difference between periods for both males and females. Tukey's test show that there are significant differences between the sizes of period I, as against both periods II and III, but no significant difference between periods II and III. The conclusion is that even a species that flies the year round in a subtropical climate may show seasonal differences in size, and the adults that emerge in the few months after the coldest ones are larger, and that this period, although extended, would correspond to early emergence in temperate climates; the rainier months of December-February correspond to peak emergence. For T. eleonorae, from Intervales State Park, also in a subtropical climate, the data are more limited but the results agree with those of $T$. illiesi. Larger samples were obtained in November and February and an analysis of these shows a very significant difference between them (Table 3).

TABLE 2

Tupiperla illiesi from Boracéia and Paranapiacaba biological stations. Analysis of forewing lengths of males and females, by period.

\begin{tabular}{|c|c|c|c|c|c|c|}
\hline \multirow{2}{*}{ sexlperiod } & \multicolumn{2}{|c|}{ I: Aug.-Nov. } & \multicolumn{2}{c|}{ II: Dec.-Feb. } & \multicolumn{2}{c|}{ III: Mar.-May } \\
\hline & $\mathbf{N}$ & mean & N & mean & N & mean \\
\hline males & 10 & $7.82 \mathrm{~mm}$ & 38 & $7.42 \mathrm{~mm}$ & 10 & $7.67 \mathrm{~mm}$ \\
\hline females & 9 & $9.56 \mathrm{~mm}$ & 25 & $8.94 \mathrm{~mm}$ & 11 & $8.90 \mathrm{~mm}$ \\
\hline & ANOVA: & males & $\mathrm{F}=8.417^{* *}$ & & & \\
\hline & & females & $\mathrm{F}=8.287^{* *}$ & & & \\
\hline TUKEY test & & $\mathrm{I} \times \mathrm{II}$ & $\mathrm{I} \times \mathrm{III}$ & $\mathrm{II} \times \mathrm{III}$ & & \\
\hline & males & $5.277^{* * *}$ & $3.298^{*}$ & $1.572 \mathrm{n} . \mathrm{s}$. & & \\
\hline & females & $5.418^{* * *}$ & $4.988^{* *}$ & $0.376 \mathrm{n} . \mathrm{s}$. & & \\
\hline
\end{tabular}


TABLE 3

Tupiperla oliveirai from Pirenópolis, Goiás State. Comparison of male and female wing lengths from samples from November, 1993, and May, 1994, t-test.

\begin{tabular}{|c|c|c|c|c|c|c|c|}
\hline sexlmonth & & November & & & May & & \\
\hline & $\mathbf{N}$ & mean & SE & N & mean & SE & $\mathbf{t}^{\text {Nov.xFeb }}$ \\
\hline males & 9 & 8.41 & 0.079 & 10 & 8.10 & 0.086 & $2.642^{*}$ \\
\hline females & 4 & 9.65 & 0.171 & 9 & 9.62 & 0.057 & 0.216 n.s. \\
\hline
\end{tabular}

TABLE 4

Tupiperla eleonorae from the Intervales State Park. Comparison of male and female wing lengths from samples from November, and February, t-test.

\begin{tabular}{|c|c|c|c|c|c|c|c|}
\hline sex\month & & November & & & May & & \\
\hline & $\mathbf{N}$ & mean & SE & N & mean & SE & $\mathbf{t}^{\text {Nov.xFeb }}$ \\
\hline males & 16 & 7.29 & 0.072 & 29 & 6.84 & 0.049 & $5.259^{* * *}$ \\
\hline females & 33 & 8.54 & 0.0651 & 35 & 8.03 & 0.055 & $5.786^{* * *}$ \\
\hline
\end{tabular}

Larger samples of T. oliveirai, especially of males, were obtained in the months of

November and May (Table 1). An analysis of these samples show a significant difference at the 0.05 level of probability between the sizes of males, but not for that of females (Table 4); the female samples, however, were smaller. These results indicate that even in the seasonal tropical climate of Central Brazil a seasonal size difference occurs .

In conclusion, seasonal size differences seem to be common in both subtropical and tropical climates in Brazil (see also Froehlich, 1990), even is species that fly all along the year, but the causes remain uncertain.

Aknowledgments - To CNPq for a Research Fellowship (301247/96-0). To my students and my son Otavio for help in field work.

\section{REFERENCES}

FROEHLICH, C. G., 1990, Size variation in Kempnyia (Plecoptera: Perlidae). pp. 347-350. In: I. C. Campbell (ed.), Mayflies and Stoneflies. Life Histories and Biology. Kluwer Academic Publishers, Dordrecht.

FROEHLICH, C. G., 1991, Flight periods of Kempnyia and Macrogynoplax (Plecoptera: Perlidae) in south-eastern Brazil. pp. 353-357. In: J. Alba-Tercedor \& A. SanchezOrtega (eds.), Overview and Strategies of Ephemeroptera and Plecoptera. Sandhill Crane Press, Gainesville.
HYNES, H. B. N., 1976, Biology of Plecoptera. Ann. Rev. Ent., 21: 135-153

McELRAVY, E. P., WOLDA, H. \& RESH, V. H., 1982, Seasonality and annual variability of caddisfly adults in a "non-seasonal" tropical environment. Arch. Hydrobiol., 94(3): 302-317.

OLIVEIRA, L. G., 1996, Aspectos da biologia de comunidades de insetos aquáticos da ordem Trichoptera Kirby, 1813, em córregos de cerrado do município de Pirenópolis, Estado de Goiás. 120p. Ph.D. Thesis. São Paulo.

WOLDA, H. \& FLOWERS, R. W., 1985, Seasonality and diversity of mayfly adults (Ephemeroptera) in a "nonseasonal" environment. Biotropica, 17(4): 330-335.

ZWICK, P., 1980, Plecoptera (Steinfliegen). Handbuch der Zoologie 26. 115p. Walter de Gruyter, Berlin. 